Volume 6 Issue 4, December 2019

Nationally Accredited Journal,

Decree No. B/4130/E5/E5.2.1/2019

\title{
Code Enforcement Of Sanctions For Notary Who Having Multiple Offices
}

\begin{abstract}
Abiem Pandya Prasojo ${ }^{1}$, Anis Mashdurohatun ${ }^{2}$ and Ngadino ${ }^{3}$
Abstract. In every office attached to someone will be accompanied by moral rules called code of ethics as well as the notary office. Code of conduct notary entire moral code is determined by the association organization "Indonesian Notary Association" (INI), where applicable, and must be obeyed by all members of the association as well as others who have positions of notary. Notary is necessary to know and understand the code of conduct notary. This code of conduct govern all actions of what can be regarded as a violation of the code of conduct and what sanctions if violated the code of conduct. In practice, a notary public notary supervised by the board of trustees. This oversight is necessary so that the notary did not ignore the majesty and dignity of the profession. The method used in this research is normative. The data used are primary data and secondary data. Primary data in the form of research conducted in the field related to the object of research and data secondary, namely in the form of legislation, library, archives, expert opinions and regulations associated with the object of research.

Discussion of the results shows that the sanction of conduct for notaries who have multiple offices are in violation of the code of conduct notary office. based on the above factors, it is important to know what is an indication of an offense involving the notary in the notary office area coverage authorized by a notary office code of ethics. Should the effort of the board of trustees for providing information about the code of conduct for all notaries to avoid misunderstandings about the ban notaries and exclusion. Therefore the role of the board of honor in the enforcement of the code of ethics notary must be implemented properly and in accordance with the applicable rules.

Keywords: Notary Code; Honor Council; Office of the Associate; Notary.
\end{abstract}

\section{Introduction}

Notary and akta product can be defined as the state attempts to create certainty and legal protection for members of the public. Given in the area of private law / civil, placing the country as a notary public official authorities have in terms of making authentic act, for the sake of proof / evidence ${ }^{4}$.

Notary is an office of trust therefore someone willing to entrust something to him as a trust $^{5}$, Position notary is an institution created by the state. As a public official should and must understand and comply with all the provisions of the legislation in force. This is an absolute must given the post of a notary office of trust in the law enforcement process. Beside that, the notary must always behave and act in accordance with the code of professional conduct Notary ${ }^{6}$.

Code of conduct notary entire moral code is determined by the association organization

\footnotetext{
${ }^{1}$ Student Master of Notary Program, Faculty of Law, UNISSULA E-mail: abiempandya13@gmail.co.id

2 Lecturer, Faculty of Law UNISSULA

${ }^{3}$ Notary / PPAT in Semarang

${ }^{4}$ Sjaifurrachman 2011, Aspek Pertanggungjawaban Notaris Dalam Pembuatan Akta, CV Mandar

Maju, Bandung, p. 33

${ }^{5}$ Ibid, p. 1

${ }^{6}$ Habib Adjie, 2015, Penafsiran tematik hukum notaris indonesia, PT Refika Aditama, Bandung, p.243
} 
"Indonesian Notary Association" (INI), where applicable, and must be obeyed by all members of the association and others who served as the notary office both in execution and in everyday life?

Code of ethics and is now recognized Notary Code Indonesian Notary Association (INI). Relationships with organizations notary profession regulated under the code of conduct notary, where the existence of a code of conduct notary is a consequence of a violation related work behavior of the Notary only to the moral sanction. Notary Code contains an element of obligation, prohibition, exceptions and penalties to be imposed if it is proved notary violated the code of ethics. Besides the code of conduct is also regulated procedures for the enforcement of the code of conduct and dismissal while as a member of $\mathrm{INI}^{8}$,

Enforcement of the code of conduct within the organization have the notary Notary institutions through the Honor Council, which set out in Article 7 of the code of ethics Notary supervision over the implementation of the Code committed by:

- At the district / city level by the Regional Board and the Regional Ethics Board;

- At the provincial level by the Regional Board and the Regional Ethics Board;

- At the national level by the Central Board and the Honorary Board of the Center.

Honorary Board of the Regional consist of three (3) members among them, a Chairman, a Vice Chairman and a Secretary, who can be appointed as a member of the Honorary Board of Regions is a regular member who has served as a notary at least five (5) years and members outstanding (former notary), who always obey the rules of clubs and the legislation in force, dedicated, loyal and meritorious and have a sense of high concern. The term of office of the Honorary Board The area is the same as the term of office of members of the Regional Board.

Notaries in carrying out its obligations as a public official, must have an office in domicile. Determination of the domicile of the notary is determined by the state through the Ministry of Justice and Human Rights (Kemenkumham). After the enactment notch region notary is obliged to carry out their duties in the domicile. Notary notch region only take in a district / city. While the region covers a provincial office. In accordance with Article 17 letter a of Notary Law, namely: "Notaries are prohibited from running beyond their positions of office".

This is also confirmed by Article 3 (8) Notary Code on Liability namely: "Establishing an office at the seat and the office is the only office for Notary concerned in carrying out everyday office tasks".

According Lumban Tobing, notary authorities in respect of the place where the deed was made, the point here every notary determined his region's age domicile. Notary authority only makes the deed in his region ${ }^{9}$. Deed made outside his territory legal force equal to the deed under hand. If the notary violates the prohibition contained in the Law on Notary and Notary Code may be penalized in the form of suspension in accordance with Article 9, paragraph (1) letter d of Law Number 2 of 2014 concerning Notary ${ }^{10}$. Thus, a notary shall make a notarial deed in the region position and his position and not allowed to have multiple offices or branches especially with the region and a different place. Therefore, it is important for notaries to be able to better understand the extent to which the sanctions were applied as a violation of the code of conduct, and whether, after the Court's decision implies that violates the law against

\footnotetext{
7 Mardani, 2017, Etika Profesi Hukum, RajaGrafindo Persada, Depok, p.128

${ }^{8}$ Ibid, p. 3

9 Tobing, Lumban, 1996, Peraturan Jabatan Notaris, Notary, Erland, Jakarta, p. 49-50

${ }^{10}$ Habieb Adjie, 2008, Sanksi Perdata \& Administratif Terhadap Notaris Sebagai Pejabat Publik, PT. Refika Aditama, Bandung, p.35
} 
Volume 6 Issue 4, December 2019

Nationally Accredited Journal,

Decree No. B/4130/E5/E5.2.1/2019

the notary Notary Code and Law Notary. The problem of this paper as to how enforcement of sanctions for violations of the code of conduct by a notary, and what problems encountered in the enforcement of sanctions against violations of the code of conduct notary.

\section{Research Methods}

This research is using normative juridical approach, using primary data and secondary data. Primary data in the form of research conducted in the field related to the object of research and secondary data, namely in the form of legislation, library, archives, expert opinions and regulations associated with the object of research.

The data collected in this research is secondary data obtained by studying and analyzing the literature and documents relating to the object of research.

\section{Discussion}

\subsection{Enforcement of Sanctions Violations of the Code of Conduct by a Notary}

The code of ethics, code means a sign that approve purposeful. While the Ethics comes from the Greek "ethos" which means nature, culture, way of life ${ }^{11}$. According to Adi Negoro in his book General Encyclopedia, as cited by Sudarno, et al, suggests: Ethics comes from the word meaning science Eticha modesty, decency science. and said Ethica (ethics, ethos, customs, manners, humanity) ${ }^{12}$. In this case, understanding also includes the broad and narrow meaning. In a broad sense, law enforcement include the values of life who live in the community. But in the narrow sense, law enforcement concerns only formal enforcement and writing only. Objectively speaking, rule of law to be enforced include formal legal sense and material law. Formal law is only concerned with regulatory legislation is written, while the material law also includes understanding the values of justice in the society.

Just as described above codes of ethics are part of the positive law, Law No. 2 of 2014 concerning Notary mention that in performing duties of a notary office must have integrity and act professionally. Notary office shall run with a trustworthy, honest, thoroughly, independently and impartially, and maintain the attitude, behavior in accordance with the code of ethics, honor, dignity, and responsibility as a notary. It is pronounced as the oath by any person who want to assume the notary. Thus it is necessary to provide guidance, development, and ongoing supervision so that all notary further improve the quality of public services.

Enforcement of the code of conduct notarized by Notary Act, Article 83, paragraph 1, namely: notary organizations establish and enforce a code of conduct notary, therefore, the rule set in the code of conduct notary, among which: Sanctions Code of Ethics; and Supervision.

But in practice in the conduct guidance, enforcement of ethical codes against the notary public notary is not always able to run well as expected and desired.

The Notary Code conducted with the regulation of Notary based on article 4 which stated that a public notary is prohibited:

- Having more than one (1) office, either branches or representative offices.

- Installing pagan Hama and / or text that reads "Notary / Notary Office" outside the

${ }^{11}$ Sadirman AM, 1990, Interaksi dan Motivasi Belajar, Eagle Press, Jakarta. p. 149

12 Sudarno, et al., 1989, Administrasi Supervisi Pendidikan, Cet.II, the March University Press, Surakarta. p. 117 
office environment.

- Doing publicity or promotion themselves, either individually or jointly, by indicating the name and position, by means of print media and / or electronics, in the form of : Advertisement; Congratulations; Condolences; Gratitude note; Marketing activities; Sponsorship activities, both in the social, religious, and sports;

- Working closely with the Bureau of services / person / legal entity that essentially act as an intermediary to seek or obtain clients.

- Signed the act that the manufacturing minuta process has been prepared by another party.

- Minuta sends to the client for signature.

- Trying or attempting in any way, so that a person moving from another Notary him, the effort was directed to clients who are concerned or through the intermediary of another person.

- Coercing clients by withholding documents that have been submitted and / or psychological pressure in order that the client remains a deed to him.

- Make efforts, either directly or indirectly lead towards the emergence of unfair competition with fellow Notaries.

- Determine the fees to be paid by the client in a lower amount of honorarium predetermined Society.

- Employing deliberately people who are still employees of the Notary office to another without the prior consent of the concerned Notary.

- Disfigure and / or blaming colleague Notary or deed made by him. In the case of a Notary face and / or find a deed made by colleagues who turned out in which there are errors that are serious and / or harm to a client, make the Notary it shall notify the colleague concerned on mistakes he made in a way that is not patronize, but to prevent things that are not desirable to the concerned clients or colleagues are.

- Forming a group of fellow colleagues and exclusive with the aim to serve the interests of an agency or institution, let alone the possibility for others to participate Notary.

- Use and include titles that are not in accordance with the applicable laws and regulations.

- Other deeds which is generally referred to as a violation of the Notary Code, including but not limited to violations of: The provisions of Act No. 30 of 2004 on Notary position; Elucidation of Article 19 paragraph (2) of Law No. 30 of 2004 concerning Notary; The contents of the oath of office Notary; ${ }^{13}$

Understanding the notary's office is not spelled out clearly and forcefully in UUJN, in the code of conduct notary also not spelled out explicitly about the notion of a notary's office. The provisions of Article 19 paragraph (1) UUJN and Article 3 point 8 and Article 4 paragraph 1 Notary Code that does not explicitly mention the definition of a notary's office, but such provisions by clearly states that notaries can only have one office to carry out his daily and Notaries are prohibited to open and operate branches, representative and all sorts of other forms.

Notary shall make a notarial deed in the region position and his position and not allowed to have multiple offices or branches especially with the region and a different place. It's written clearly in article 4 paragraph 1 if you have multiple offices or branches including a code of conduct and a violation can be sanctioned if proven to have multiple offices. However, the setting on the sanctions that can be imposed on a notary who opened a branch office or multiple offices not mentioned expressly in the development of UUJN and Notary Code. Notary Supervisory Council only give verbal

${ }^{13}$ Act No. 2 of 2014 On Notary, Citra Umbara, Bandung, p. 115 
Volume 6 Issue 4, December 2019

Nationally Accredited Journal,

Decree No. B/4130/E5/E5.2.1/2019

reprimand to the notary who violate the code, ask the nameplate on the office's status as a branch office released and asked for the existing scale branch office activity is terminated. So is the Honorary Board which provides the same sanction to the notary who had branch offices.

\subsection{Problems Encountered in the Enforcement of Sanctions Against Violations of the Code of Conduct Notary}

In the enforcement of sanctions violations of the code of conduct, there are some problems in its application. Problems of enforcement of the code of ethics there are 2 factors: factors sanctions and supervision factor. Because different ethical sanctions with positive legal sanction so there is a deterrent effect, and for their monitoring was supervised by a colleague / friend alone, so less effect among notary authority, although the members of the Honorary Board is a notary-senior notary.

In case of problems regarding the enforcement Notary Code by the Honorary Board of the Notary states that the code created by the firm and clear and established the Honorary Council, but in fact on the ground is still a lot of violations, for example easy to them is a violation of the deed exceed the maximum limit in one day is 20 certificates per day, violations of advertising notary by making wreaths. Such violations occur because of ignorance will notary codes of conduct to violations that occur because of pretending not to know, or even some that are not concerned with the existence of a code of conduct notary.

Apparently these shortcomings provide an opportunity for professionals weak in faith to do deviate from the code of conduct of his profession. In order for the code of ethics adhered to by the Public Notary required personal consciousness in order to maintain the behavior, maintain the authority of Notary and Notary Organization. Regarding the behavior as a notary, Habib Adjie stated there are four main things to be aware of the ${ }^{14}$ :

- Having a competent moral integrity; In carrying out the task of his profession, a notary must have moral integrity capable and full awareness of his position. In this case, all moral considerations should underpin the implementation of tasks profession.

- Must be honest with the client nor myself (intellectual honesty); Notary to be honest, not only on the client, as well as to himself. Notaries must know the extent to which means, do not give promises only to make the client happy and always use our services.

- Aware of the limits of its authority Notaries must be aware of the limits of their authority. Notaries must comply with applicable laws and regulations about how far he can act and what is allowed and what not to do. How far the boundaries, the rules and the sanctions that would be obtained if violated.

- Not solely based on money; A notary must still adhere to the sense of justice, is not affected by the amount of money, and not merely pursue formal proof tool creates legal certainty, but ignore the sense of justice.

\section{Closing}

\subsection{Conclusion}

From the description of law enforcement for notaries who have multiple offices or

${ }^{14}$ Habib Adjie, 2015, Penafsiran Tematik Hukum Notaris Indonesia, Refika Aditama, Bandung. p. 86 
branch offices as a violation of Law No. 2 of 2014 concerning Notary and Notary Code, obtained the following conclusions:

- Notaries are only allowed to open one (1) office. Notary shall make a notarial deed in the region position and his position and not allowed to have multiple offices or branches especially with the region and a different place. The provision is explicitly stated in Article 19 paragraph (1) UUJN, Article 3 point 8 and Article 4 paragraph 1 Notary Code. However, the setting on the sanctions that can be imposed on a notary who opened a branch office or multiple offices not mentioned expressly in UUJN and Notary Code. Notary Supervisory Council only give verbal reprimand to the notary who violate the code, ask the nameplate on the office's status as a branch office released and asked for the existing scale branch office activity is terminated. So is the Honorary Board which provides the same sanction to the notary who had branch offices. The sanction is less precise. Because I think the effect of the offense so much. It would be better if the notary who violates the code of conduct received a letter of reprimand in writing, so that the violation may be recorded and may be monitored whether the notary is still operating a branch office or not.

- Problems encountered in the enforcement of sanctions against violations of the code of conduct is sanctioned less notary deterrent effect against violators of the code of conduct of the Notary Public. Penalty ethics in contrast to positive legal sanction so there is a deterrent effect, and for their monitoring was supervised by a colleague / friend alone, so less effect Notary Supervisory prestige among the Assembly and the Council of Honor.

\subsection{Suggestion}

- To avoid similar violations in the future, the authors feel the need for improvement in the Act mainly pay attention to the sanctions that may be imposed against violators of these provisions. Law should be strictly and clearly set on the sanctions to be implemented and is intended to ensure a deterrent effect and to prevent similar violations in the future.

- Notary Supervisory Council and the Board of Ethics is expected to do everything possible in its duty to supervise and train the Notary and implement truthfully regulations regarding various matters related about the obligations of the notary. So that in the future there are no violations reoccur in the generation Notary later, the Assembly of Trustees Notaries and Honorary Council is expected to provide counseling and more understanding to the Notary new duties and prohibitions set forth in the Law on Notary and Notary Code.

\section{References}

[1] Habib Adjie, 2008, Sanksi Perdata \& Administratif Terhadap Notaris Sebagai Pejabat Publik, PT. Refika Aditama, Bandung.

[2] Habib Adjie, 2015, Penafsiran Tematik Hukum Notaris Indonesia, PT Refika Aditama, Bandung.

[3] A.M, Sadirman, 1990, Interaksi dan Motivasi Belajar, Rajawali Press, Jakarta.

[4] Mardani, 2017, Etika Profesi Hukum, RajaGrafindo Persada, Depok.

[5] Sjaifurrachman, 2011, Aspek Pertanggungjawaban Notaris Dalam Pembuatan Akta, CV Mandar Maju, Bandung.

[6] Sudarno, dkk, 1989, Administrasi Supervisi Pendidikan, Cet. II, Sebelas Maret University Press, Surakarta.

[7] Tobing, Lumban.G.H.S. 1996. Peraturan Jabatan Notaris, Erlangga, Jakarta. 